\title{
SENYAWA KOMPLEKS Fe(II)-BASA SCHIFF: SINTESIS, KARAKTERISASI SPEKTROSKOPI DAN STUDI TERMAL
}

\author{
Zipora Sembiring ${ }^{1 *}$, Agung Abadi Kiswandono ${ }^{1}$ \\ ${ }^{1}$ Jurusan Kimia, FMIPA,Universitas Lampung \\ Jalan Prof. Dr. Soemantri Brodjonegoro No.1 Bandar Lampung 35145 \\ zipora.sembiring@fmipa.unila.ac.id
}

Artikel Info
Diterima
tanggal
29.06 .2019
Disetujui
publikasi
tanggal
30.10.2020
Kata kunci :
Azometin,
basa Schiff,
entropi,
eksotermik

\section{ABSTRAK}

Telah dilakukan sintesis, karakterisasi dan analisis termal senyawa kompleks dari ion Fe(II) dengan ligan basa Schiff DPCO-p-T. Sintesis senyawa kompleks dilakukan dengan menggunakan metode variasi kontnyu dari Job berdasarkan perbandingan mol. Hasil perbandingan mol antara ion $\mathrm{Fe}(\mathrm{II})$ dengan ligan basa Schiff diperoleh $1: 3$. Berdasarkan perbandingan mol tersebut, senyawa kompleks [Fe(DPCO-p-T $\left.)_{3}\right] \mathrm{SO}_{4}$. disintesis dan diperoleh kristal murni berwarna coklat terang, titik leleh: $167-168^{\circ} \mathrm{C}$ dengan rendemen hasil 77,68\%. Berdasarkan identifikasi dan karakterisasi struktur, senyawa kompleks $\left[\mathrm{Fe}(\mathrm{DPCO}-\mathrm{p}-\mathrm{T})_{3}\right] \mathrm{SO}_{4}$ memiliki gugusgugus azometin, azo dan metil. Analisis termal dengan DTA-TG menunjukkan perubahan struktur pertama terjadi pada suhu $150-200{ }^{\circ} \mathrm{C}$, reaksi endotermik dengan kehilangan massa sebesar $9,4 \%$ yang menandakan lepasnya 1 mol ion $\mathrm{SO}_{4}{ }^{2-}$ sebagai ion penetral senyawa kompleks. Perubahan kedua terjadi reaksi eksotermik pada suhu $200-275{ }^{\circ} \mathrm{C}$ kehilangan massa sebesar 83,5\% ekivalen dengan kehilangan massa 3 mol ligan yang terkoordinasi pada senyawa kompleks. Perubahan massa berikutnya terjadi pada suhu $300-400{ }^{\circ} \mathrm{C}$ menunjukkan kehilangan massa sebesar $6,7 \%$ merupakan residu dari senyawa kompleks yaitu metal oksida. Nilai entropi aktivasi ditemukan dalam bentuk negatif menunjukkan bahwa proses dekomposisi dengan laju reaksi lebih rendah dari yang normal dan kompleks teraktifkan memiliki sifat yang lebih menentukan dari pada reaktan hal ini disebabkan karena chemisorptions dari hasil dekomposisi.

\section{ABSTRACT}

The synthesis, characterization, and thermal analyzis of complex compound of $\mathrm{Fe}(\mathrm{II})$ ion and schiff base ligand DPCO-p-T has been conducted. The synthesis of complex compound has been conducted by employing the method of Job's Continuous Variation based on mol comparison. The result of mol comparison between ion Fe(II) with Schiff base ligand is 1:3. Based on that result, complex compound $\left[\mathrm{Fe}(\mathrm{DPCO}-\mathrm{p}-\mathrm{T})_{3}\right] \mathrm{SO}_{4}$ is synthesized and resulted light brown colored pure cryztal, melting points of 167-168 ${ }^{\circ} \mathrm{C}$ with rendement $77.68 \%$. Based on indetification and structur characterization, complex compound [ $\left.\mathrm{Fe}(\mathrm{DPCO}-\mathrm{p}-\mathrm{T})_{3}\right] \mathrm{SO}_{4}$ have azomethine group, azo and methyl. Termal analyzes with DTA-TG showed the first structure change is in the 150-200 ${ }^{\circ} \mathrm{C}$, endothermic reaction with weight loss 9.4\% showing $1 \mathrm{~mol}$ ion $\mathrm{SO}_{4}{ }^{2-}$ as complex compound neutrilizer ion is off. The second change is exothermic reaction in $200-275{ }^{\circ} \mathrm{C}$ and loosing weght $83,5 \%$ equivalent with loosing weight 3 mol ligan that is coordinated with complex compound. The third mass change in 300-400 ${ }^{\circ} \mathrm{C}$ showing weight loss in $6.7 \%$ was residue of methyl oxide complex compound. Activation entropy value is negative and showed that decomposition process with a lower reaction flow than the normal and activated complex has more determined traits than reactant which is caused by chemisorptions from decomposition outcome.

doi: http://dx.doi.org/10.23960/aec.v5.i2.2020.p123-134

Anal.Environ.Chem. 


\section{PENDAHULUAN}

Senyawa kompleks dapat disintesis dari ligan dengan ion logam serta melakukan peran penting dalam berbagai bidang dan sistem biologis. Salah satu ligan yang dapat digunakan adalah basa Schiff. Kompleks logam transisi-basa Schif memiliki banyak aplikasi di bidang antitumor, aktivitas katalis dan antikorosi indikator (Osowole et al., 2008; Kumar et al., 2009) serta sistem yang dapat meniru model enzim (Montazerozohari et al., 2008). Kemampuan ligan basa Schiff untuk bertindak sebagai ligan netral pada logam transisi, terutama $\mathrm{Ni}$ (II), $\mathrm{Cu}$ (II), Co (II), Fe(II) sebagai akseptor telah banyak dipulikasikan dalam berbagai laporan.

Sifat dari ligan untuk dapat membentuk kompleks dengan ion logam pusat sangat penting dalam kimia koordinasi Erdem et al., 2009 dan Jevtovic et al., 201)1. Interaksi ini dapat diamati dalam termodinamika dan aspek kinetik untuk mempelajari efek serta membandingkan perilaku kompleks terhadap aplikasinya sebagai katalis. Basa Schiff adalah kelas senyawa favorit dalam bidang biologi dan memainkan peran penting dalam kimia koordinasi (Liu et al., 2006).. Basa Schiff aromatik dalam bentuk netral dan terdeprotonasi telah digunakan untuk bereaksi dengan ion logam transisi bilangan oksidasi (II), kompleks yang terbentuk menunjukkan variabel stoikiometri dalam logam ke ligan dengan rasio yang berbeda pada bilangan koordinasi (Pouralimardan et al., 2007). Kelanjutan dari studi sebelumnya pada logam transisi kompleks basa Schiff, kami melaporkan di sini sintesis, karakterisasi spektroskopi dan analisis termal logam Fe(II) hasil adisi yang berpotensi sebagai ligan donor yang memiliki gugus-gugus fungsi azo, hidrazo, metil dalam lingkungan ligan. Adanya gugus-gugus fungsi pada lingkungan ligan dapat menyetabilkan senyawa kompleks.

Penelitian ini melaporkan hasil analisis dari termogravimetri dan spektroskopi untuk memprediksi gugus fungsi, kestabilan termal dan memperkirakan parameter kinetik dalam senyawa kompleks Fe(II) dengan basa Schiff difenilkarbazon-p-toluidin. Mengingat aplikasi industri senyawa kompleks, maka perilaku termal dari senyawa kompleks berguna untuk dipelajari. Sintesis Basa Schiff dalam penelitian ini bersifat fleksibel dalam pembentukan dan mengandung atom donor keras dan lunak.

doi: http://dx.doi.org/10.23960/aec.v5.i2.2020.p123-134

Anal.Environ.Chem. 


\section{METODE}

\section{Alat dan Bahan Penelitian}

Alat-alat yang digunakan pada penelitian ini adalah alat-alat gelas yang lazim dipakai di laboratorium, desikator, pengaduk megnetik, neraca analitis, penangas air, labu hisap Buchner, vakum desikator, spektrofotometer ultraungu-tampak (UV-Vis) merek Hitachi model 150/20, Fourier Transform Infra Red (FT-IR), Hitachi TGA DTA 7300 series, magnetic susceptibility balance (MSB), dan diffraktometer Sinar-X. Jenis bahan yang digunakan di dalam penelitian ini secara umum dari Merk dalam bentuk p.a yaitu garam Mohr, 1,5-difenilkarbazona, p-toluidina, asam asetat, etanol, metanol, $\mathrm{H}_{2} \mathrm{SO}_{4(\mathrm{p})}$, dan akuades.

\section{Sintesis Senyawa Kompleks Fe(II)-Ligan Basa Schiff DPCO-p-T}

Sebelum dilakukan sintesis senyawa kompleks, terlebih dahulu dilakukan sintesis ligan basa Schiff DPCO-p-T. Ligan basa Schiff disintesis dari 1,5-difenilkarbazon dan p-toluidin dengan perbandingan mol 1:1. Sintesis dilakukan menggunakan metode kondensasi dalam pelarut etanol. Hasil kristal ligan basa Schiff digunakan untuk sintesis senyawa kompleks dengan ion Fe(II) dari garam Mohr. Sintesis dilakukan dengan menggunakan metode variasi kontinyu dari Job. Hasil kristal senyawa tersebut dianalisis dengan spektrofotometer UV-Vis untuk mendapatkan perbandingan mol optimum dari sintesis senyawa kompleks tersebut (Osowole et al. 2008; Khattack et al., 2008).

\section{Penentuan Gugus Fungsional pada Ligan asa Schiff dan Senyawa Kompleks}

Ligan basa Schiff dan senyawa kompleks hasil sintesis dikarakterisasi dengan menggunakan spektrofotometer inframerah untuk mengetahui gugus fungsional yang ada didalamnya. Karakterisasi dilakukan di daerah bilangan gelombang 400-4000 $\mathrm{cm}^{-1}$. Pada ligan basa Schiff, biasanya gugus azometina atau imina memberikan pita serapan yang khas pada daerah sekitar $1600 \mathrm{~cm}^{-1}$.

\section{Analisis Sifat Termal Senyawa Kompleks dengan DTA/TG}

Differential thermal analysis dan thermogravimetric (DTA/TG) merupakan teknik untuk mengukur perubahan massa dari suatu senyawa sebagai fungsi dari suhu ataupun waktu. Pada suhu tertentu terjadi dekomposisi senyawa sampel. Spesi yang terdekomposisi ataupun yang

doi: http://dx.doi.org/10.23960/aec.v5.i2.2020.p123-134 Anal.Environ.Chem. 
tersisa diketahui dengan cara membandingkan massa sampel pada suhu tersebut terhadap massa awal. Cuplikan sampel diletakkan pada cawan platina, dipanaskan pada laju konstan sebesar 10 ${ }^{\circ} \mathrm{C}$ /menit. Pengukuran dilakukan pada kisaran suhu $20-1000{ }^{\circ} \mathrm{C}$.

\section{HASIL DAN PEMBAHASAN}

\section{Sintesis Senyawa Kompleks Fe(II)-Ligan basa Schiff DPCO-p-T}

Sintesis senyawa kompleks menggunakan metode variasi kontinyu diperoleh perbandingan mol antara basa Schiff dengan ion Fe(II) yaitu $1: 3$ (Gambar 1). Hasil sintesis senyawa kompleks diperoleh kristal murni berwarna coklat terang, titik leleh: $167-168{ }^{\circ} \mathrm{C}$ dengan hasil rendemen $77,68 \%$.

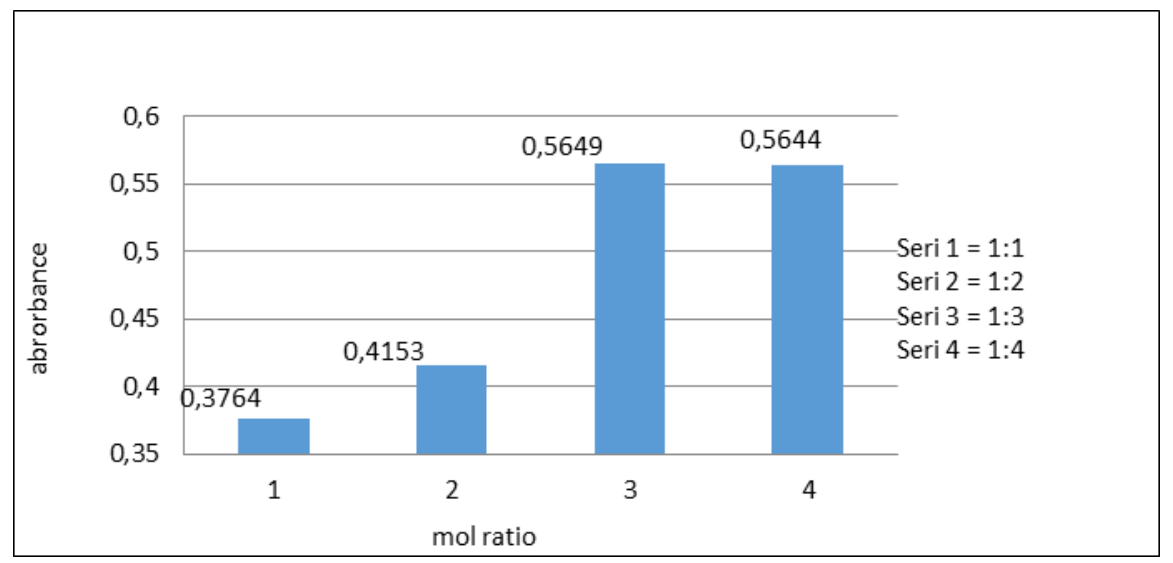

Gambar 1. Kurva metode Job's variasi kontinyu perbandingan mol antara ion $\mathrm{Fe}^{2+}$ dengan ligan basa Schiff DPCO- $p$-T

\section{Analisis Struktur Ligan DPCO-p-T dan Senyawa Kompleks $\left[\mathrm{Fe}(\mathrm{DPCO}-p-\mathrm{T})_{3}\right]^{2+}$. dengan Spektrofotometer Inframerah}

Gugus-gugus fungsi yang ada dalam struktur DPCO, senyawa ligan basa Schiff DPCO-p$\mathrm{T}$ dan senyawa kompleks $\left[\mathrm{Fe}(\mathrm{DPCO}-p-\mathrm{T})_{3}\right]^{2+}$ ditentukan dengan menggunakan spektrofotometer inframerah pada daerah bilangan gelombang $400-4000 \mathrm{~cm}^{-1}$. Data spektra inframerah dipakai untuk melihat gugus fungsi yang terlibat dalam pembentukan senyawa kompleks. Data spektra inframerah disajikan dalam Tabel 1.

doi: http://dx.doi.org/10.23960/aec.v5.i2.2020.p123-134 Anal.Environ.Chem. 
Tabel 1. Data Spektra inframerah dari ligan basa Schiff DPCO-p-T dan kompleks $\mathrm{Fe}(\mathrm{II})-\mathrm{DPCO}-p-\mathrm{T}$.

\begin{tabular}{lllllllll}
\hline Senyawa & $v(\mathrm{M}-\mathrm{N})$ & $v(\mathrm{~N}-\mathrm{H})$ & $v(\mathrm{C}-\mathrm{N})$ & $v(\mathrm{C}=\mathrm{O})$ & $v(\mathrm{~N}=\mathrm{N})$ & $v(\mathrm{C}=\mathrm{N})$ & $v(\mathrm{C}-\mathrm{H})$ & $\gamma(\mathrm{N}-\mathrm{H})$ \\
& - & 3311,22 & 1287,93 & 1713,28 & 1497,42 & 1662,20 & 3054,37 & 881,7 \\
DPCO & - & 3310,72 & 1288,5 & - & 1495,74 & 1662,47 & 3055,24 & 881,20 \\
DPCO-p-T & & & & & 1496,76 & 1658,72 & 3055,24 & 879,54 \\
Fe(II)-DPCO-p-T & 447,49 & 3309,85 & 1288,45 & & & & &
\end{tabular}

Menurut Sastrohamidjojo (1992) dan Supratman (2010) beberapa gugus fungsi spektra serapan dari inframerah muncul pada daerah karakteristik yakni gugus amina $(-\mathrm{N}-\mathrm{H})$ pada daerah 3500-3300 $\mathrm{cm}^{-1}$, pita regang $\mathrm{C}-\mathrm{H}$ aromatis di daerah 3100-3000 $\mathrm{cm}^{-1}$, gugus $-\mathrm{C}-\mathrm{N}$ - di daerah 1350-1250 $\mathrm{cm}^{-1}$, gugus azo $-\mathrm{N}=\mathrm{N}$ - pada daerah $1575-1450 \mathrm{~cm}^{-1}$, kelompok gugus $-\mathrm{C}=\mathrm{N}$ - daerah 1690-1650 $\mathrm{cm}^{-1}$ dan kibasan N-H daerah $900-750 \mathrm{~cm}^{-1}$.

Berdasarkan data spektra pada Gambar 2 dan 3, beberapa pita serapan yang sama untuk semua senyawa DPCO, DPCO- $p$-T dan kompleks muncul pada daerah: vibrasi ulur yang khas untuk gugus amina sekunder muncul pada daerah rentangan 3311,22; 3310,72 dan 3309,85 cm daerah 1605,16 ; 1604,55 dan 1604,77 $\mathrm{cm}^{-1}$ menunjukkan vibrasi bengkokan N-H. Vibrasi kibasan (wagging) $\gamma(\mathrm{N}-\mathrm{H})$ teramati muncul pada daerah 881,$7 ; 881,20$ dan $879,54 \mathrm{~cm}^{-1}$. Serapan cincin $\mathrm{C}=\mathrm{C}$ aromatis sering saling tumpang tindih dengan vibrasi bengkokan $\mathrm{N}-\mathrm{H}$ yang muncul

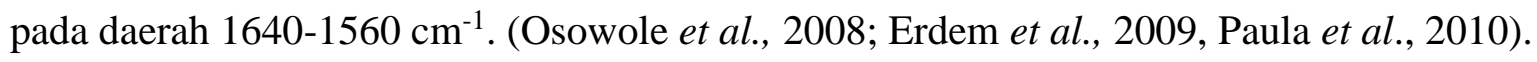

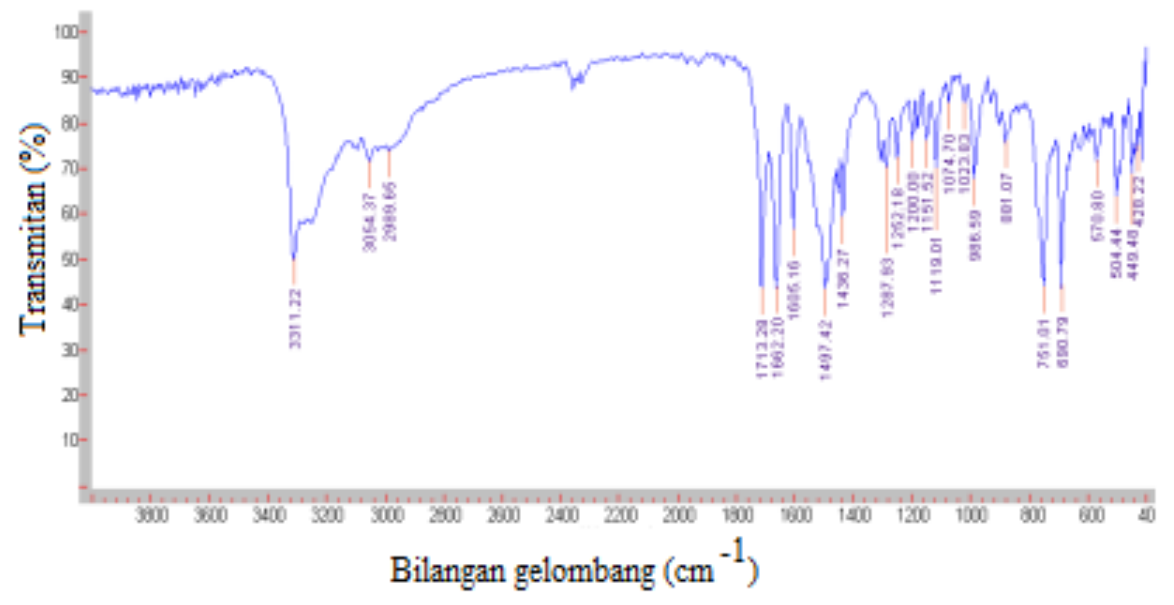

Gambar 2. Spektrum Inframerah DPCO

doi: http://dx.doi.org/10.23960/aec.v5.i2.2020.p123-134 Anal.Environ.Chem. 


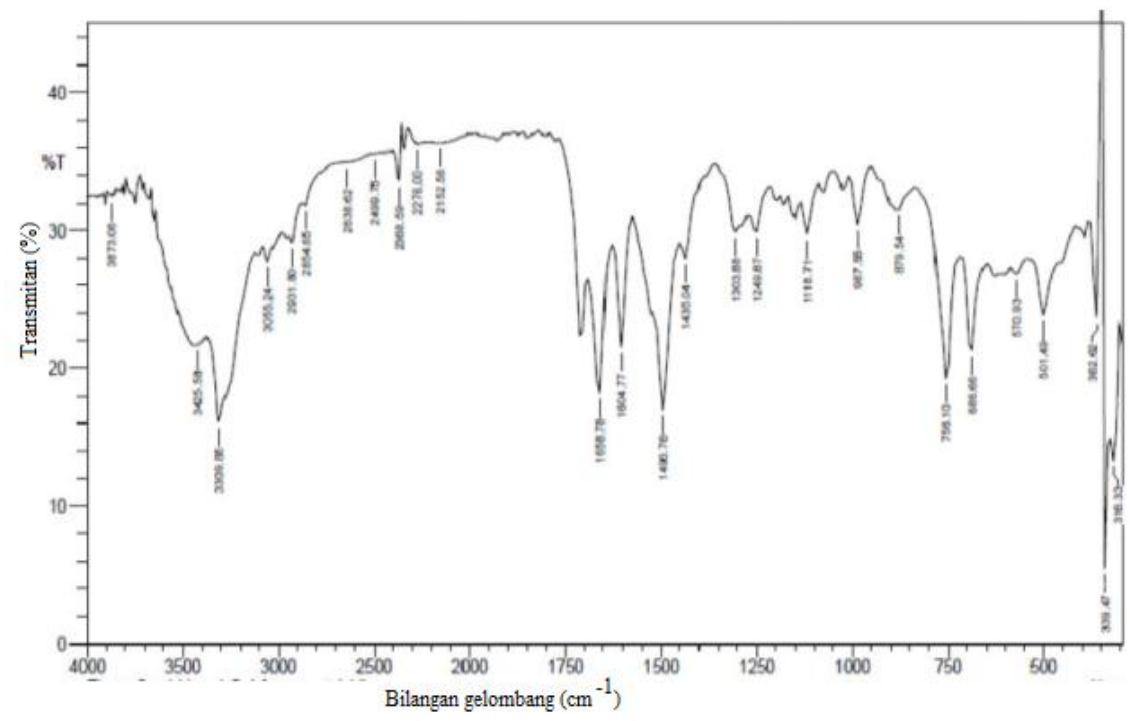

Gambar 3. Spektrum Inframerah Ligan Basa Schiff DPCO-p-T

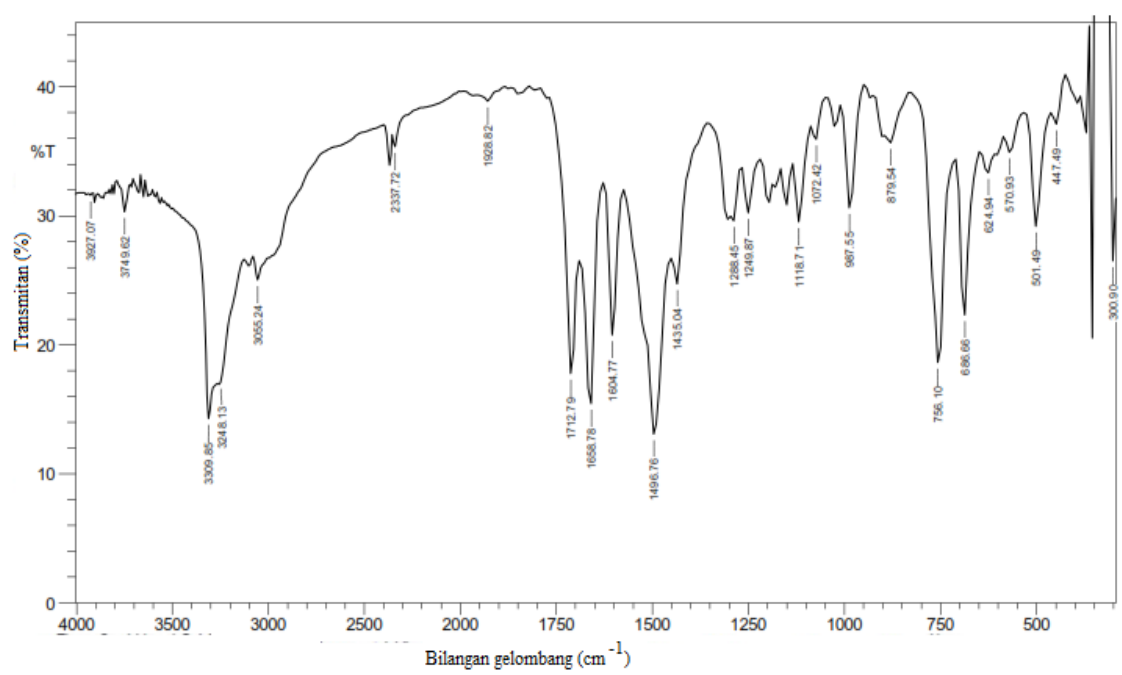

Gambar 4. Spektrum Inframerah Senyawa Kompleks Fe(II) DPCO-p-T

Daerah 1700-1730 $\mathrm{cm}^{-1}$ merupakan daerah spesifik dan kuat untuk gugus karbonil $\mathrm{C}=\mathrm{O}$ dari keton (Paula et al., 2010). Gambar 2 dan 3 menunjukkan bahwa hilangnya gugus karbonil $\mathrm{C}=\mathrm{O}$ dari keton pada ligan basa Schiff di daerah $1713,28 \mathrm{~cm}^{-1}$ membuktikan bahwa gugus karbonil dari senyawa DPCO telah mengalami reaksi adisi membentuk gugus azometina atau imina dengan $p$-toluidina.

Gugus azometina atau imina $(-\mathrm{C}=\mathrm{N}-)$ memberi serapan vibrasi regang pada daerah bilangan gelombang $1690-1650 \mathrm{~cm}^{-1}$, akan tetapi gugus $-\mathrm{N}-\mathrm{CO}-\mathrm{N}$ - seperti urea yang ada pada 
DPCO juga memberi serapan pada daerah yang sama sehingga muncul serapan pada daerah tersebut baik untuk DPCO maupun DPCO-p-T (Erdem et al., 2009). Gugus imin pada senyawa ligan basa Schiff bebas dan senyawa kompleks (Gambar 4), vibrasi ulur $-\mathrm{C}=\mathrm{N}$ - ditunjukkan dengan munculnya pita serapan pada daerah $1662,47 \mathrm{~cm}^{-1}$ dan $1658,72 \mathrm{~cm}^{-1}$ sebagai puncak serapan sedang. Turunnya intensitas pada daerah vibrasi ulur rentangan $-\mathrm{C}=\mathrm{N}-$ menandai terjadinya interaksi pada gugus azometin dan terbentukknya ikatan koordinasi antara ligan dan ion logam Fe(II). Hal ini diperjelas lagi dengan munculnya pita serapan pada senyawa kompleks yang terjadi di daerah bilangan gelombang $447,49 \mathrm{~cm}^{-1}$ sebagai gugus (-M-N-) (Osowole et al., 2008; Erdem et al., 2009).

Gugus-gugus lainnya seperti gugus azo $-\mathrm{N}=\mathrm{N}-$ dan gugus $\mathrm{C}-\mathrm{H}$ aromatis, vibrasi ulur spektrum IR dalam daerah $1575-1450 \mathrm{~cm}^{-1}$ untuk $\mathrm{N}=\mathrm{N}$ dan $3100-3000 \mathrm{~cm}^{-1}$ untuk $\mathrm{C}-\mathrm{H}$ aromatis. Berdasarkan hasil penelitian menunjukkkan bahwa semua senyawa yaitu senyawa DPCO, DPCO- $p$ - $\mathrm{T}$ dan kompleks memiliki gugus azo $-\mathrm{N}=\mathrm{N}$ - dan gugus $\mathrm{C}-\mathrm{H}$ aromatis dengan adanya spektra serapan yang muncul di daerah 1497,42 $\mathrm{cm}^{-1} ; 1495,74$ dan $1496,76 \mathrm{~cm}^{-1}$ untuk gugus azo dan $3054,37 \mathrm{~cm}^{-1 ;} 3055,24$ dan $3055,24 \mathrm{~cm}^{-1}$ untuk gugus C-H aromatis.

\section{Analisis Termal dan Studi Kinetik Senyawa Kompleks [Fe(DPCO-p-T) $\left.)_{3}\right]_{S_{4}}$ dengan DTA-TG}

Analisis dekomposisi termal senyawa kompleks dilakukan dengan menggunakan metode Differential Thermal Analysis-Thermogravimetric (DTA-TG) pada kisaran suhu $25-1000{ }^{\circ} \mathrm{C}$ dengan kecepatan kenaikan suhu $10{ }^{\circ} \mathrm{C} /$ menit. Analisis termal senyawa kompleks pada kurva DTA-TG menunjukkan 1 (satu) puncak terjadi reaksi endotermik pada suhu 150-200 ${ }^{\circ} \mathrm{C}$ dan 2 puncak reaksi eksotermik pada suhu $100-275^{\circ} \mathrm{C}$ dan $300-400{ }^{\circ} \mathrm{C}$. Perubahan-perubahan struktur terjadi mulai suhu $150{ }^{\circ} \mathrm{C}$ sampai $375{ }^{\circ} \mathrm{C}$ (Khanmohammadi et al., 2009). Perubahan struktur sesuai dengan persen kehilangan massa senyawa kompleks seperti yang disajikan pada Tabel 2.

Kajian tentang perubahan struktur senyawa kompleks dari kurva DTA-TG yang ditunjukkan pada Gambar 5, menjelaskan bahwa suhu $25^{\circ} \mathrm{C}$ hingga $150{ }^{\circ} \mathrm{C}$ tidak ada persentase penurunan atau kehilangan massa dari senyawa kompleks, hal ini menandakan tidak adanya molekul air terkoordinasi pada senyawa kompleks.

doi: http://dx.doi.org/10.23960/aec.v5.i2.2020.p123-134 Anal.Environ.Chem. 
Table 2. Data dekomposisi termal untuk ligan dan kompleks

\begin{tabular}{lccccc}
\hline $\begin{array}{l}\text { Formula } \\
\text { Empiris }\end{array}$ & $\begin{array}{c}\text { Rentang } \\
\text { Suhu } \\
\text { Dekomposisi } \\
\left({ }^{\circ} \mathrm{C}\right)\end{array}$ & $\begin{array}{c}\text { Suhu puncak } \\
\text { DTG }\left({ }^{\circ} \mathrm{C}\right)\end{array}$ & $\begin{array}{c}\% \text { massa } \\
\text { yang hilang } \\
\text { (analisis) }\end{array}$ & $\begin{array}{c}\% \text { massa yang } \\
\text { hilang (teori) }\end{array}$ & $\begin{array}{c}\text { Molekul yang } \\
\text { hilang }\end{array}$ \\
\hline Fe(II)- & $150-200$ & 160 & $9,4 \%$ & $8,6 \%$ & $\mathrm{SO}_{4}{ }^{2-}$ \\
DPCO- $p$-T & $200-275$ & 240 & $83,5 \%$ & $86,65 \%$ & $\begin{array}{c}3 \text { mol Ligan } \\
\text { Oksida logam } \\
\text { (residu) }\end{array}$ \\
\hline
\end{tabular}

Perubahan struktur pertama terjadi pada suhu $150-200{ }^{\circ} \mathrm{C}$ dengan persen kehilangan massa sebesar 9,4\% yang hampir setara dengan lepasnya $1 \mathrm{~mol}$ ion $\mathrm{SO}_{4}{ }^{2-}$ sebagai ion penetral senyawa kompleks, berdasarkan teori sebesar $8,6 \%$ (Tabel 2). Pelepasan ion $\mathrm{SO}_{4}{ }^{2-}$ dari senyawa kompleks ditandai dengan adanya reaksi endotermik pada suhu $160,8^{\circ} \mathrm{C}$. Perubahan kedua terjadi reaksi eksotermik pada suhu $240,2{ }^{\circ} \mathrm{C}$ dimana senyawa kompleks pada suhu $200-275^{\circ} \mathrm{C}$ kehilangan massa sebesar 83,5\%, berdasarkan teori 86,65\% ekivalen dengan kehilangan massa 3 mol ligan yang terkoordinasi pada senyawa kompleks. Perubahan massa berikutnya terjadi pada suhu $300-400{ }^{\circ} \mathrm{C}$ menunjukkan kehilangan massa sebesar $6,7 \%$ merupakan residu dari senyawa kompleks yaitu metal oksida yang sesuai teori sebesar $6,32 \%$.

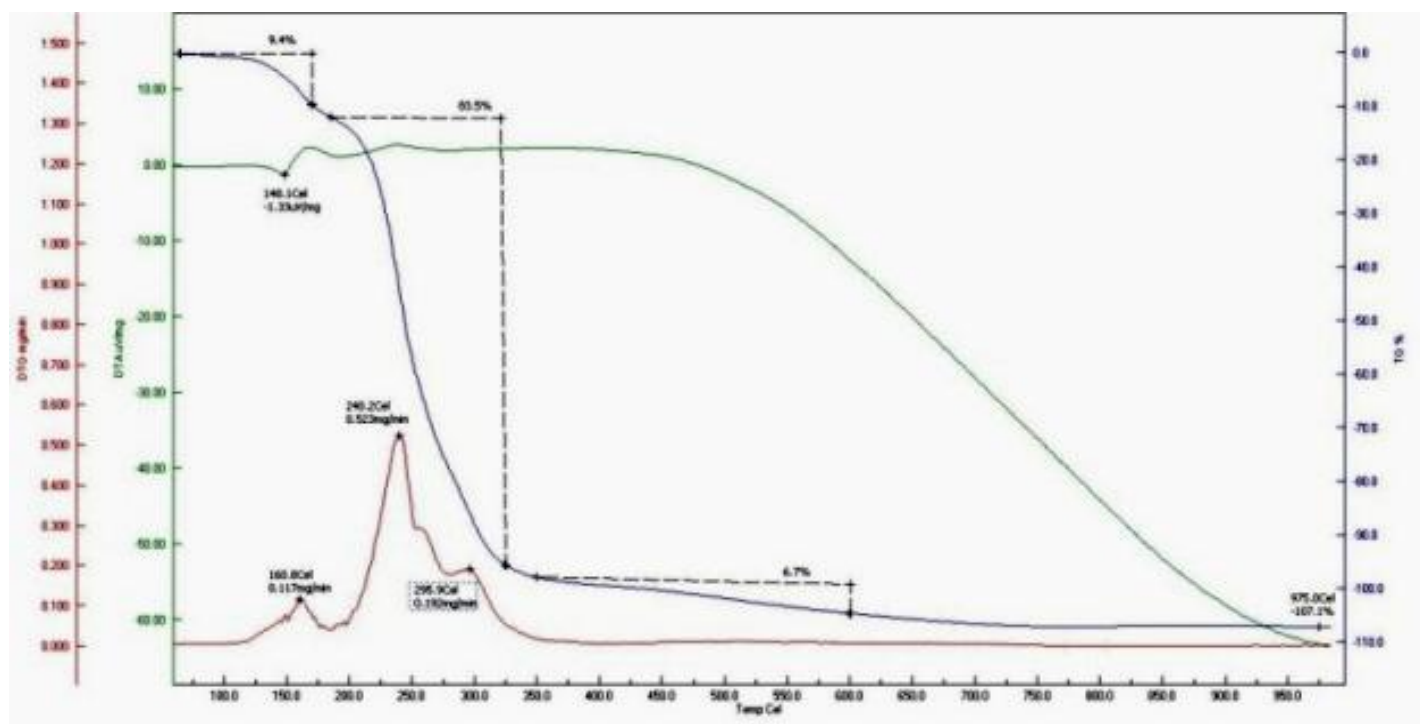

Gambar 5. Kurva termogravimetri DTA/TG untuk kompleks [Fe(DPCO- $\left.p-\mathrm{T})_{3}\right] \mathrm{SO}_{4}$

doi: http://dx.doi.org/10.23960/aec.v5.i2.2020.p123-134 Anal.Environ.Chem. 
Berdasarkan uraian diatas maka senyawa kompleks dari ligan basa Schiff 1,5difenilkarbazona-p-toluidina (DPCO- $p$-T) dan ion besi(II) merupakan senyawa kompleks yang memiliki bilangan koordinasi 6 dan ligan bidentat (Gambar 6).
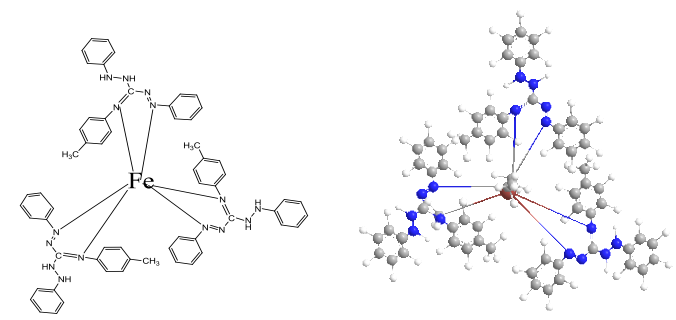

Gambar 6. Struktur Molekul Senyawa Kompleks $\left[\mathrm{Fe}(\mathrm{DPCO}-\mathrm{p}-\mathrm{T})_{3}\right]^{2+}$

\section{Analisis Termografimetrik dan Kinetik Menggunakan DTA-TG}

Analisis termografimetrik senyawa kompleks $\left[\mathrm{Fe}(\mathrm{DPCO}-\mathrm{p}-\mathrm{T})_{3}\right] \mathrm{SO}_{4}$ dilakukan pada rentang suhu $25-1000{ }^{\circ} \mathrm{C}$. Dekomposisi terjadi dalam 3 tahap pada rentang suhu, suhu puncak DTG serta persen dekomposisi tertera pada Tabel 2. Parameter aktivasi termodinamik pada proses dekomposisi senyawa kompleks dievaluasi melalui kurva TGA (Gambar 5) menggunakan metode Coats-Redfern (Yalcin et al., 2001; Sedaghat et al., 2011). Persamaan yang digunakan persamaan 1.

$$
\ln \left[-\ln (1-\alpha) / \mathrm{T}^{2}\right]=-\mathrm{E}^{*} / \mathrm{RT}+\ln \left[\mathrm{AR} / \theta \mathrm{E}^{*}\right]
$$

dimana: $\alpha$ adalah fraksi dekomposisi yang diberikan pada suhu $\mathrm{T}(\mathrm{K}), \mathrm{R}$ adalah tetapan gas $\left(8.314 \mathrm{Jmol}^{-1} \mathrm{~K}^{-1}\right)$, A adalah faktor frekuensi $\left(\mathrm{min}^{-1}\right), \theta$ adalah laju pemanasan $\left(\mathrm{K} \mathrm{min}^{-1}\right)$ dan $\mathrm{E}^{*}$ adalah energi aktivasi $\left(\mathrm{kJ} \mathrm{mol}^{-1}\right)$. Nilai Fraksi dekomposisi $(\alpha)$ dapat diperoleh dari: $\alpha=\frac{W}{W_{f}}$ dimana: $\mathrm{w}$ adalah hilangnya massa sampel pada suhu $\mathrm{T}$ dan $\mathrm{W}_{\mathrm{f}}$ adalah hilangnya massa sampel pada akhir reaksi dalam hal ini $\mathrm{W}_{\mathrm{f}}=3,414 \mathrm{mg}$. W adalah harga-harga yang sangat penting dan dapat digunakan untuk perhitungan kuantitatif dari perubahan komposisi. Dengan plot $-\ln [-\ln (1-$ $\alpha) / \mathrm{T}^{2}$ ] vs $1 / \mathrm{T}$ pada kisaran suhu $140-200{ }^{\circ} \mathrm{C}, 200-300{ }^{\circ} \mathrm{C}$ dan $300-400{ }^{\circ} \mathrm{C}$ didapat garis lurus menunjukkan order1 (Gambar 7). Nilai $E^{*}$ diperoleh dari slope dan nilai A diperoleh dari intercept.

doi: http://dx.doi.org/10.23960/aec.v5.i2.2020.p123-134 Anal.Environ.Chem. 

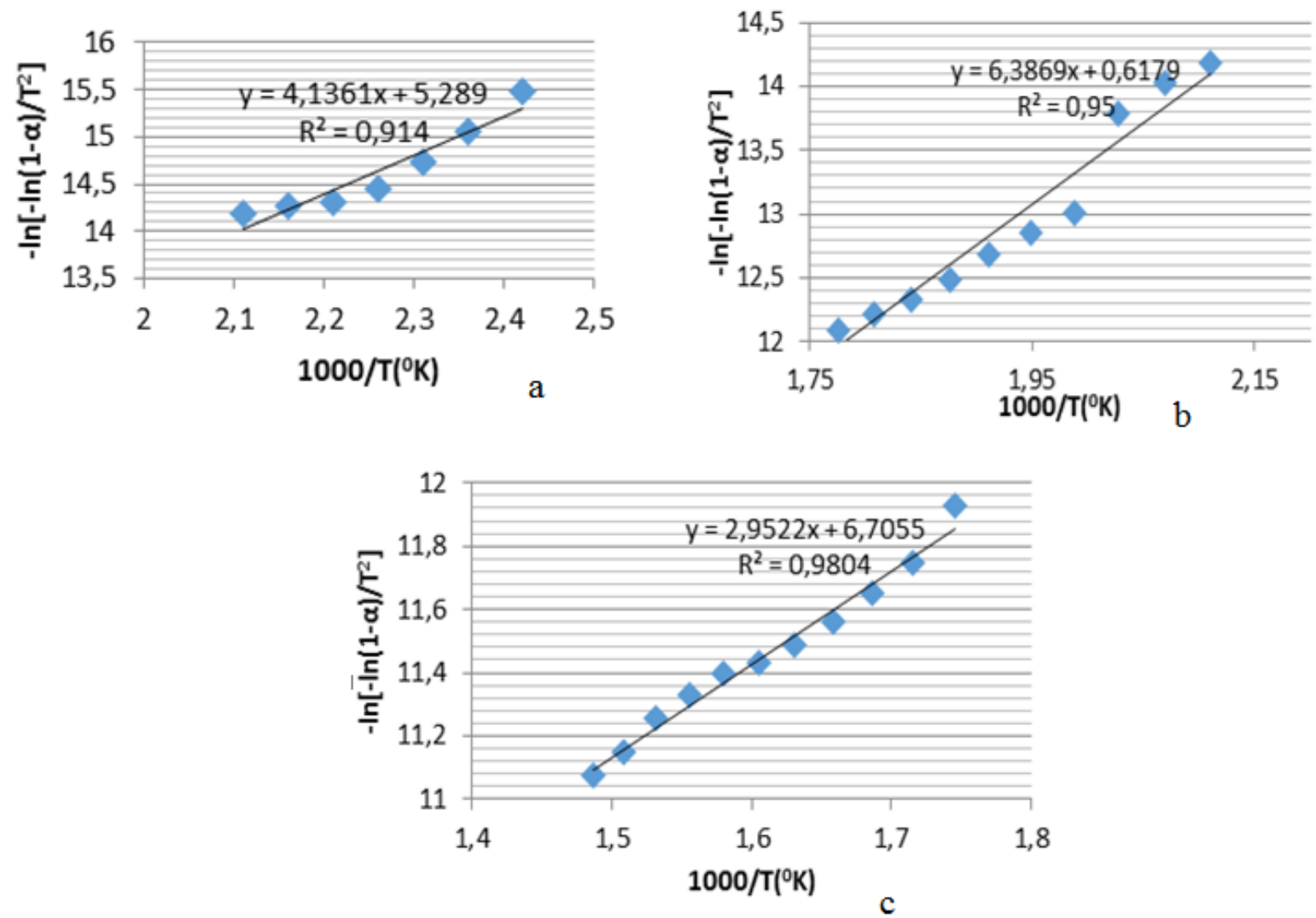

Gambar 7. Plot Metode Coats-Redfern untuk dekomposisi Kompleks pada suhu (a) $140-200{ }^{\circ} \mathrm{C}$, (b) $200-300^{\circ} \mathrm{C}$ dan (c) $300-400{ }^{\circ} \mathrm{C}$

Entropi aktivasi $\left(\Delta \mathrm{S}^{*}\right)$, entalpi aktivasi $\left(\Delta \mathrm{H}^{*}\right)$ dan perubahan energi bebas aktivasi $\left(\Delta \mathrm{G}^{*}\right)$ masing-masing dihitung dengan menggunakan persamaan 2, 3 dan 4

$$
\Delta \mathrm{S}^{*}=\mathrm{R} \ln \left(\mathrm{Ah} / \mathrm{k}_{\mathrm{B}} \mathrm{T}_{\mathrm{s}}\right)
$$

$$
\Delta \mathrm{H}^{*}=\mathrm{E}^{*}-\mathrm{RT}
$$

$$
\Delta \mathrm{G}^{*}=\Delta \mathrm{H}^{*}-\mathrm{T} \Delta \mathrm{S}^{*}
$$

dimana:

$\mathrm{k}_{\mathrm{B}}=$ tetapan Boltzman $\left(1,3806 \times 10^{-23} \mathrm{~J} / \mathrm{K}\right)$

$\mathrm{h}=$ tetapan Plank's $\left(6,626 \times 10^{-34} \mathrm{~J} . \mathrm{s}\right)$

$\mathrm{T}_{\mathrm{s}}=$ suhu puncak DTG

doi: http://dx.doi.org/10.23960/aec.v5.i2.2020.p123-134

Anal.Environ.Chem. 
Tabel 3. Data aktivasi termodinamik untuk dekomposisi termal senyawompleks

\begin{tabular}{clcccccc}
\hline $\begin{array}{c}\text { Tahapan } \\
\text { Kompleks }\end{array}$ & $\mathrm{R}^{2}$ & $\begin{array}{c}\mathrm{T}_{\mathrm{s}} \\
\left({ }^{0} \mathrm{~K}\right)\end{array}$ & $\begin{array}{c}\mathrm{E}^{*} \\
\left(\mathrm{~kJ} \mathrm{~mol}^{-1}\right)\end{array}$ & $\begin{array}{c}\Delta \mathrm{H}^{*} \\
\left(\mathrm{~kJ} \mathrm{~mol}^{-1}\right)\end{array}$ & $\mathrm{A} \mathrm{( \textrm {s } ^ { - 1 } )}$ & $\begin{array}{c}\Delta \mathrm{S}^{*} \\
\left(\mathrm{~J} \mathrm{~K}^{-1} \mathrm{~mol}^{-1}\right)\end{array}$ & $\begin{array}{c}\Delta \mathrm{G}^{*} \\
\left(\mathrm{~kJ} \mathrm{~mol}^{-1}\right)\end{array}$ \\
\hline I & 0,914 & 433 & 34,39 & 30,79 & $81 \times 10^{5}$ & $-115,76$ & 80,91 \\
II & 0,950 & 513 & 53,09 & 48,79 & $75 \times 10^{3}$ & $-156,09$ & 128,86 \\
III & 0,980 & 568 & 24,54 & 19,84 & $24 \times 10^{6}$ & $-108,98$ & 81,74 \\
\hline
\end{tabular}

Dalam Tabel 3 tertera nilai entropi aktivasi ditemukan dalam bentuk negatif untuk kompleks, hal ini menunjukkan bahwa proses dekomposisi dengan laju reaksi lebih rendah dari yang normal dan kompleks teraktifkan memiliki sifat yang lebih menentukan dari pada reaktan hal ini mungkin disebabkan karena chemisorptions dari hasil dekomposisi (Yalcin, 2001; Sedaghat et al., 2011).

\section{KESIMPULAN}

Penelitian sintesis senyawa kompleks besi(II) dengan ligan basa Schiff 1,5difenilkarbazona telah dilakukan dengan metode Job's variasi kontinyu perbandingan mol. Hasil studi sintesis senyawa kompleks dapat disimpulkan bahwa senyawa kompleks [Fe(DPCO-p$\left.\mathrm{T})_{3}\right]^{2+}$ yang diperoleh dari perbandinga mol $1: 3$, berwarna coklat terang dengan hasil rendemen 77,68\%, memiliki titik leleh: $167 \pm 1{ }^{\circ} \mathrm{C}$. Struktur ligan basa Schiff DPCO- $p$-T dan senyawa kompleks $\left[\mathrm{Fe}(\mathrm{DPCO}-p-\mathrm{T})_{3}\right]^{2+}$ terdapat gugus azometina, azo dan hidrazon.

\section{DAFTAR PUSTAKA}

Erdem, E., Yildrim, E. S., Kilincarslan, R., and Kabay, N. 2009. Synthesis and Characterization of azo-linked Schiff Base and their Nickel(II), Copper(II), and Zinc(II) Complexes. Transition Met. Chem. 34, 167-174.

Jevtovic, V., Cvetkovic, D. \& Vidovic, D. 2011. Synthesis X-Ray Characterization and Antimicrobial Activity of Iron(II) and Cobalt(III) Complexes with the Schiff Base Derived from Pyridoxal and Semicarbazide or S-methylisothio semicarbazide. J. Iran. Chem. Soc. Vol. 8. No. 3, 727-733.

Khanmohammadi, H., Salehifard, M., \& Abnosi, M. H., 2009. Synthesis, Characterization, Biological and Thermal Studies of $\mathrm{Cu}$ (II) Complexes of Salen and Tetrahedrosalen Ligands. J. Iran. Chem. Soc. Vol. 6, No. 2, 300-309.

doi: http://dx.doi.org/10.23960/aec.v5.i2.2020.p123-134 Anal.Environ.Chem. 
Khattak, R. I., Naqvi, I., \& Akhyar M. F., 2008. Kinetics and Mechanism of the Oxidation of a Ferrous Complex with an a,a'-Diimine Chelate Ligand by Ceric Sulfate in Aqueous Acidic Medium by UV-Vis Absorption Spectroscopy. J. Iran. Chem. Soc. Vol. 5 No. 4, 631-640.

Kumar, S., Dhar, N. D., \& Saxena, N. P. 2009. Applicatioan of Metal Complexes of Schiff Base. A Review. J. Sci. \& Indust. Research, 68, 181-187.

Liu., Jian-ning., Bo-Wan-Wu., Bing Zhang \& Yongchun Liu. 2006. Syntesis and Characterization of Metal Complex of $\mathrm{Cu}(\mathrm{II}), \mathrm{Ni}(\mathrm{II}), \mathrm{Zn}(\mathrm{II} 0, \mathrm{Co}(\mathrm{II}), \mathrm{Mn}$ (II) and $\mathrm{Cd}(\mathrm{II})$ with Tetradentate Schiff Bases. Turk. J. Chem. 30, 41-48.

Montazerozohari, M., Hossein, H. M., Zamami, F. L. \& Musavi, S. A. R. 2008.Catalytic Oxidative decarboxylation of some arylacetic acids promoted by new $\mathrm{Mn}$ (II) and $\mathrm{Fe}(\mathrm{III})$ Schiff base Complexes. Arkivoc (XI), 238-246

Osowole, A. A. 2008. Syntheses and Characterization of Some Tetradentate Schiff-Base Complexes and Their Heteroleptic Analogues. E-Journal of Chemistry. Vol. 5. No. 1, 130-135.

Paula, A. A. M., Ralph, E. D., Skrobot, E. D., Rosa, I. L. V. 2010. Synthesis, Characterization and Catalytic Study of [N, N'-bis (3-ethoxysalicylidene)(xylylenediamine)oxovanadium(IV) complex. Inorganic Chemistry Communications. Elsevier. 10, 255-261.

Pouralimadan, O., Anne-Chamayon, C., Janiak, C., Hosseini, H-Monfered. 2007. Hydrazone Schiff base-Manganese(II) Complexes, Synthesis Crystal Structure and Catalytic reactivity. Inorg. Chimica Acta. 360, 1599-1608.

Sastrohamidjojo, H. 1992. Spektroskopi Inframerah. Penerbit Liberty, Yogyakarta.

Sedaghat, T. and Monajjemzadeh, M. 2011. Some New Organotin(IV) Schiff Base Adducts: Synthesis, Spectroscopic Characterization and Thermal Studies. J. Iran. Chem. Soc., Vol. 8, No. 2, 477-483.

Supratman, U., 2010, Elusidasi Struktur Senyawa Organik. Penerbit Widya Padjadjaran.

Yalcin, T, 2001, Thermogravimetric Investigation of the Dehydration Kinetics of KSF, K10 and Turkish Bentonite. Turk. J. Chem. 25, 333-339.

doi: http://dx.doi.org/10.23960/aec.v5.i2.2020.p123-134 Anal.Environ.Chem. 